\title{
A conversation with Robert Lefkowitz
}

$\mathbf{R}$ obert Lefkowitz, physician-scientist from Duke University and the 2012 Nobel laureate in chemistry for his studies of GPCRs has recently written a memoir called A Funny Thing Happened on the Way to Stockholm, and we couldn't resist the opportunity to ask Dr. Lefkowitz (Figure 1) to reflect more extensively on a life well lived and a career full of phenomenal insights and ample laughter. See the full interview at https://www.jci.org/videos/ cgms to hear his reflections on competition in academia as well as the push and pull of a life as a physician-scientist.

JCI: Can you start by telling us about your family?

Lefkowitz: My mother was a homemaker and a force to be reckoned with. My father was kind of quiet and restrained. It was my mother's drive to make sure I achieved all that I might. I was not blessed with any athletic talent, but in sports like softball, I pushed myself to practice until I became one of the better players. I lifted weights because I grew up in a neighborhood that had some anti-Semitic gangs and we felt we had to protect ourselves. I was very studious, and I was an obsessive reader. I was an only child, so I was often alone, and books were my friends.

JCI: You knew you wanted to be a physician from about age eight?

Lefkowitz: From that very young age, I had the deep sense that I was destined to be a doctor, and I can't remember a time when I ever thought about anything else. One of the major sources for that was my family physician. Dr. Joseph Feibush was an internist and family physician. On his house calls, he let me play with his stethoscope, and I was just all in.

Bronx High School of Science seemed to me the obvious place to prepare and then Columbia University. But even at Columbia, I was a man in a hurry. I had graduated high school at age 16 with a fair bit of course credit, so I was able to finish college in three years. At age 19, I graduated with a major in chemistry, then went on to Columbia Medical School.

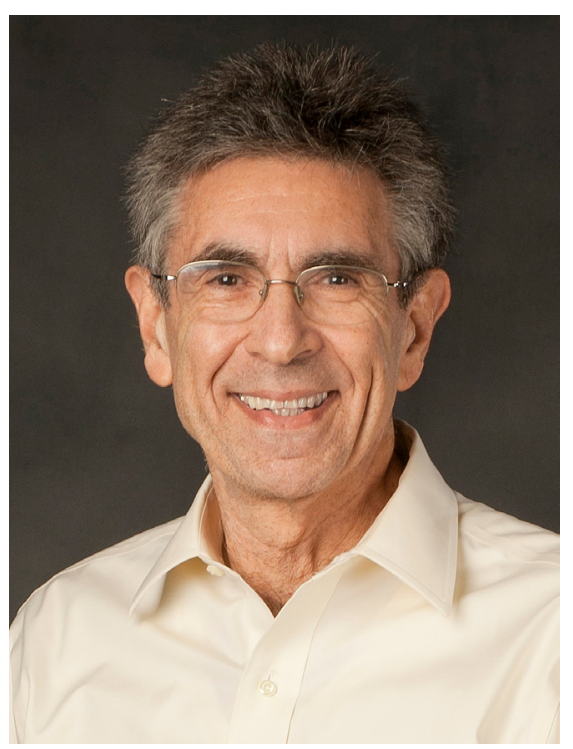

Figure 1. Robert Lefkowitz

I did my house staff training at Columbia-Presbyterian; I was totally dedicated to being a practicing physician. It was only through the serendipity of my graduating at the height of the Vietnam War and being drafted into the US Public Health Service that I ever was introduced to doing research. This program, which was technically called the Associate Training Program, went by a little kind of tonguein-cheek term: the yellow berets. This was a take-off on the green berets, the elite commando forces, yellow presumably implying cowardice, but we didn't think of it that way. In fact, we use the term to this day as a badge of honor: in over just an eight-year period from 1964 to 1972, there were about 50 to 100 a year who went into the program. From that group, ten of us went on to win the Nobel Prize. In my class that arrived in 1968 and left in 1970, there were four of us: myself, Mike Brown, Joe Goldstein, and Harold Varmus. And there was another guy in our class who has done okay: Tony Fauci.

I had a rude awakening when I started at the NIH for my two-year assignment. At the one-year point, I had made no progress whatsoever and was clinically depressed. I was not cut out to be a scientist. I was already making plans to finish my clinical training at the Massachusetts General Hospital. My father was very supportive; in my first year at the NIH, I went back to New York for Thanksgiving and had a long talk with my dad. He was a bookkeeper, a simple man, and he always seemed to have a way of talking me off the ledge. He said, "What do you care if the research isn't working? Do your time, and then you'll go on to be the cardiologist you and I always dreamed of." I went back to the NIH feeling much better about things. He died three weeks later of his fourth myocardial infarction, and that haunted me for years. During my second year at the NIH, things began to work and I got a taste of what it was like to actually figure something out, publish some papers.

JCI: What were you working on at NIH?

Lefkowitz: I was assigned to two mentors, Jesse Roth and Ira Pastan, both very notable scientists, way ahead of their time. They were interested in the idea that there might be receptors for hormones and drugs. This was a very controversial idea, not generally accepted at the time. They set me going on a project to prove that there were receptors by using radioactively labeled hormones to label the receptors in membranes and tissues.

In the first phase, I was trying to prove that I could make radioactive iodinated ACTH and prove its biological activity; that was a real sticking point. I eventually succeeded. When I left the NIH, I was imbued with the idea that there might be such a thing as a receptor, having shown for ACTH that I could bind the radioactively labeled hormone to sites in the membrane, which had all the characteristics that you might expect for such a receptor. Although we did not prove that receptors existed, it suggested we were on the right track. But I didn't want to work on ACTH or any other peptide hormone. I wanted to work on something relevant to the cardiovascular system. I linked up with a mentor at the Massachusetts General Hospital, where I was doing my residency, Edgar Haber. He had developed a radioimmunoassay 
for aldosterone and wanted me to work on that. I wasn't interested because there was reason to believe that aldosterone receptors, if they existed, were a totally different type. They weren't linked to the enzyme adenylyl cyclase; they weren't in the plasma membrane; they were inside the cell.

I look back on my conversation with him in awe of my chutzpah. Here I was, this junior guy begging to have a lab to work in, and he was chief of cardiology. As a cardiology fellow, I told him I wouldn't work on aldosterone. To his credit, he asked what I did want to work on. I said, "These beta blockers have just been approved for use, and they're based on the idea that there might be something like a $\beta$-adrenergic receptor for adrenaline." He gave me his blessing, and I was off to the races. I made a little progress on that during my 2.5 years in his laboratory.

When I came to Duke in 1973, I really focused my attention on that, and within a year, I had a good radioactive binding assay for the $\beta$-adrenergic receptor. That was what opened everything up, and from there we were just flying.

JCI: Why did you decide to go to Duke and how did you manage to recruit superstars from the get-go?

Lefkowitz: Had I stayed at Harvard, I would have been assigned a laboratory as follows: there was a storage cabinet in my mentor's lab. It was probably about 50 square feet. And they would have pulled out the shelves and put in one lab bench. At Duke, they were offering me 1500 square feet of prime space in a new building, support for two postdoctoral fellows and a technician for three years, and operating costs and start-up costs. The proviso was that if I got grant support, I wouldn't get that money. The guy who recruited me, Jim Wyngaarden, who was chair of medicine, was shrewd enough to realize I would get grant support, so he never had to lay out a penny.

I had no way of hiring anybody. Nobody had heard of me. So I asked Andy Wallace, the chief of cardiology, to keep an eye out for potential fellows. A few weeks later, he mentioned Lee Limbird, whose husband was coming to Duke for orthopedic residency, and she was just finishing her $\mathrm{PhD}$ in biochemistry. I immediately signed her up. The second hire was a bit unusual: I got a letter while I was still at MGH from Marc Caron, who was getting his $\mathrm{PhD}$ in biochemistry at
University of Miami. He thought I was a professor, and he thought my publications were interesting and asked if I'd be interested in taking him on as a postdoc. I wrote back, "Absolutely. I'd be delighted to take you on."

This was before I had even gotten the job at Duke, and I did nothing to disabuse him of his misconception that I was a faculty member. He got a fellowship, and shortly thereafter I accepted the position at Duke, and I wrote him, "Good news, I'm moving to Duke, and so your trip won't be all the way to Boston, you'll just have to move halfway, to Durham."

I arrived on June 28. July 1, this kid named Rusty Williams walks into my office. He was at the very beginning of his MD-PhD at Duke. He said, "I'm looking for somebody to work with, and I haven't really felt good about any of the people I've talked to." I told him all about receptors, and he signed up.

What's the common feature in all of this? I'll tell you one other story in case you haven't got the message yet. Fast-forward about ten years later; a guy named Brian Kobilka is finishing his medical residency at Wash U. He wants to come to Duke for a cardiology fellowship, which is a four-year fellowship with two years of research. He wanted to talk to me, but I was out of town, so Marc Caron talked to him. A month or two later, he decided to make a second visit to Duke because he was really serious about it. Again, I'm out of town. So again, we don't speak, but he decides to come anyway and to work with me even though we had not met. We worked together to clone the gene that encodes for the $\beta$-adrenergic receptor. Twenty years later and by then he was a professor at Stanford - we would share the Nobel Prize.

JCI: You're riding a wave of success after cloning the receptor, but you're very circumspect in your book about being jealous when [Alfred] Gilman and [Martin] Rodbell won the Nobel in 1994.

Lefkowitz: I suffered that indignity on two separate occasions, ten years apart. In 1994, after having already cloned the receptors and discovered other families of proteins called the arrestins and $G$ protein-coupled receptor kinases, they give the prize to Rodbell and Gilman for discovering $G$ proteins in 1994, and everybody says, "Wait a minute, there was a third spot open there, and receptors and G proteins, like love and marriage, horse and carriage, they go together." I agreed with them. It was not that I spent time worrying about winning Nobel Prizes, but then when it was in my face and worse yet, I was asked by multiple journals to write the commentaries about it, that stung.

I was a little down in the mouth, and almost any time there's a prize awarded, there are always going to be controversies. But you get over it, so that was the end of that. Then, worse yet in a sense, in 2004, [Linda] Buck and [Richard] Axel won the prize for discovering olfactory receptors and elucidating the mechanisms of olfaction.

Now olfaction, like taste, begins with a family of $\mathrm{G}$ protein-coupled receptors. In the case of olfaction, it's a huge family, probably like 300 different GPCRs, and that whole subfamily were discovered by Buck and Axel in 1991 - that was five years after we cloned the $\beta$ receptor. And their success was based on their coming up with a very clever strategy, wherein they developed degenerate PCRs based on the sequences of previously cloned GPCRs. Everybody in the field knew that the taste and smell receptors were GPCRs. There were only about eight sequences that they could use. Most of them were from my lab, so absent our work, they could have done nothing. And so now the Nobel Committee is awarding the two of them the prize for the olfactory receptors and, again, nothing for us. That one hurt even more.

So when that phone call came from Stockholm on Wednesday, October 10th, 2012, not that it sticks in my mind or anything, I wasn't jumping up and down; that was not the way I felt. My main emotion was one of quiet satisfaction. At last it finally happened, and the growing realization that never again would I ever have the answer the question, "Bob, when are you going to win the Nobel Prize?"

JCI: What other profession could have kept you engaged?

Lefkowitz: Being a stand-up comic is one that has always really appealed to me. The only other one I could imagine would be a courtroom attorney. I would have to be pleading cases in front of a jury, not a research guy or a professor of law - I'd want to be in the courtroom as a prosecutor, not a defense attorney.

Ushma S. Neill 